WMJ (Warmadewa Medical Journal), Vol. 3 No. 1 Mei 2018, Hal. 6-14

\title{
Functional Gait Assessment to Predict the Risk of Falls in Elderly
}

\author{
Saktivi Harkitasari ${ }^{1}$, Cokorda Agung Wahyu Purnamasidhi ${ }^{2}$, RA Tuty Kuswardhani ${ }^{3}$ \\ ${ }^{1}$ Neurology Department Universitas Warmadewa \\ ${ }^{2}$ Internal Medical Department Udayana University/Sanglah Hospital Denpasar \\ ${ }^{3}$ Geriatric Division Internal Medicine Department, Udayana University /Sanglah Hospital Denpasar

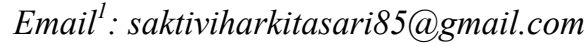

\begin{abstract}
Aging process represents the natural process which is inevitable. It is caused by a biological factor that goes naturally resulting in the anatomical, biochemical and physiological changes. The natural changes contribute to falling in elderly. The objective of this study was to assess the falling prediction in elderly by using Functional Gait Assessment. This study used a cross-sectional research design with falling prediction as the variable. Forty-three elderly in Panti Werdha Wana Seraya (aged 60-103 years, - mean of 77.48 \pm 1.61 ), selected according to the inclusion criteria, were included in the study. The data were collected using Functional Gait Assessment and analyzed both descriptively and statistically. The results showed that the elderly had a high risk of falls. Functional Gait Assessment showed that 41 of 43 subjects scored $<20$, indicating that $95.3 \%$ elderly had a bad gait assessment. Based on gender distribution, bad gait assessment was found in 10 male subjects $(23.3 \%)$ and in 33 female subjects $(76.7 \%)$. Eight subjects (18.6\%) had 1time falls, 26 subjects $(60.4 \%)$ had 2 times falls, and $9(20.9 \%)$ had 3 times falls. We found there was a significant correlation between score of Functional Gait Assessment and the number of falls based on the bivariate analysis $(\mathrm{r}=0.36 ; \mathrm{p}<0.01)$. It is concluded that Functional Gait Assessment can be used to predict the risk of falls in elderly.
\end{abstract}

Keywords: Falls prediction, Elderly, Functional Gait Assessment

\begin{abstract}
Abstrak
Proses penuaan merupakan proses alami, yang tidak dapat dihindarkan. Hal ini disebabkan oleh faktor biologis yang terjadi secara alami yang mempengaruhi perubahan anatomi, biokimia dan fisiologis. Perubahan-perubahan alami ini berkontribusi pada kejadian jatuh pada lansia. Tujuan dari penelitian ini adalah untuk menggambarkan prediksi jatuh pada lansia dengan menggunakan penilaian Functional Gait Assessment. Penelitian ini menggunakan desain penelitian potong lintang. Dengan jumlah sampel 43 lansia yang terlibat, diambil sesuai kriteria inklusi. Variabel yang dinilai adalah prediksi risiko jatuh pada lansia. Data dikumpulkan menggunakan Functional Gait Assessment dan kemudian dianalisis secara statistik. Empat puluh tiga lansia di Panti Werdha Wana Seraya (usia 60-103 tahun, dengan rata-rata 77,48 $\pm 1,61$ ) diikutkan dalam penelitian. Hasilnya menunjukkan bahwa lansia memiliki risiko jatuh yang tinggi. Penilaian Functional Gait Assessment menunjukkan bahwa 41 dari 43 responden mendapat nilai $<20$, hal itu berarti bahwa 95,3\% lansia memiliki hasil penilaian gaya berjalan yang buruk. Berdasarkan distribusi jenis kelamin, hasil penilaian gaya berjalan yang buruk ditemukan pada 10 pasien laki-laki $(23,3 \%)$ dan 33 pasien perempuan (76,7\%). Terdapat 8 responden (18,6\%) mengalami 1 kali jatuh, 26 responden $(60,4 \%)$ mengalami 2 kali jatuh, dan 9 responden (20,9\%) mengalami 3 kali jatuh. Akhirnya, kami menemukan bahwa terdapat korelasi yang signifikan antara skor Functional Gait Assessment dan jumlah kejadian jatuh berdasarkan analisis bivariat $(r=0,36 ; p<0,01)$. Dapat disimpulkan bahwa Functional Gait Assessment dapat digunakan untuk memprediksi risiko jatuh pada lansia.
\end{abstract}

Kata kunci: Prediksi Jatuh, Lansia, Functional Gait Assessment. 


\section{INTRODUCTION}

Fall is a physical problem that is often experienced by the elderly as a result of the aging process ${ }^{[1]}$. Fall can cause a serious trauma, pain, paralysis and even death. Fall creates fear and loss of selfconfidence in the elderly limiting their daily activities that lead to decreased quality of life of the elderly who have experienced it. To overcome these problems, appropriate treatment is required to prevent the incidence of fall. Assessing the gait of elderly can prevent falls. Gait in elderly can be assessed by examination by the tool of Functional Gait Assessment (FGA) ${ }^{[2]}$.

The incidence of falls in nursing homes is known to be 3 times higher than in ones' own homes ${ }^{[3]}$. Elderly nursing home of Panti Werdha Wana Seraya is one of such elderly nursing homes in the city of Denpasar, with elderly residents numbering 48 persons (as of January-August 2014). According to an interview with the nursing officer of the Panti Werdha Wana Seraya done in July 2014, it was known that approximately $60 \%$ of the 52 elderly residents had experienced falls in 2011, which resulted in 3 elderly were hospitalized and the others were treated ambulatory due to only mild bruises and sprains. According to the nursing personnel, fall incident was due to the aging condition of the elderly who are prone to falling, particularly in the bathroom with slippery floor.

Aging can cause physiological changes in the musculoskeletal system in varied ways. One of them is as a result of changes in the quality and quantity of the muscles ${ }^{[1]}$. Decreased muscle strength of the lower extremities can lead to inertia of motion and short steps, by which the feet cannot tread strongly; hence it is easier to be shaky, difficult or too late to anticipate interference like slipping and tripping. Some of these indicators can increase the risk of falls in elderly ${ }^{[3]}$. The elderly may experience low self-esteem or fear of falling again, fear of not being able to do activities of daily life (ADL), or social rejection, which in turn can lead to depression and withdrawal. The result is a decrease in activity and a further decline in the quality of life ${ }^{[2]}$.

It is mainly important to maintain the elderly to be as independent as possible and for as long as possible in a safe environment. A safe environment is an environment that provides stability, protection, peace, and freedom from fear, anxiety, and commotion. For the elderly, safety and security are as important as the needs of the basic physiological needs such as food and water ${ }^{[2]}$. Focused efforts on preventing falls by identifying risk factors for falls through examination of gait using FGA is expected to make a major improvement in the maintenance of quality of life of the elderly, help the elderly maintain their functional ability and independence as well as reduce health care costs for the elderly. In the examination of gait by using FGA, assessments are done based on the ability to run, change the speed of walking, walk by looking to the left and to the right, walk to look up and down, run by $180^{\circ}$ rotation, walk with step over shoe boxes, walk around the box shoes, and go up and down stairs, all to get a score to be considered as safe for independent ambulation. Those factors, with recognition of the limits of ability of the elderly, are expected to be able to predict in advance the occurrence of fall in the elderly.

Studies on predicting the fall risk have been conducted with different tools, instruments, and variables. A predictive study to the fall risk using an easily assessed clinical variable in practice has been carried out for outpatients ${ }^{[12]}$. The process was performed through five clinical variables, covering history of falls in the last 12 months, change in gait, and history of loss of balance in 12 months, slowing of the walking speed, and impaired sight. As a result, it was found that the fall risk can be predicted through clinical variables. In predicting the risk of fall, fuzzy classifier designed through genetic algorithm (GA) can also be applied as the that was conducted by Hassan et al. ${ }^{[13]}$ In fact, a combination of 
the gait features can result in significant for the fuzzy classifier to detect falls-risk gait behavior.

Furthermore, the risk of fall prediction in patients suffering from Parkinson disease (PD), multiple sclerosis (MS), and stroke has also been carried out by multicenter prospective cohort study ${ }^{[14]}$. In this investigation, predication of the risk of fall was done using functional scale. It is found that high risk of fall is significantly caused by the PD, MS, and stroke.

Gait assessments covering selfreported walking difficulties, quantitative gait, and clinical evaluation are the assessments that can be used in predicting the risk of falls ${ }^{[15]}$. It is believed that such multiple modes of gait evaluation are promising in producing accurate results of the risk of fall predication. There should be a space for one assessment tool to be effective in predicting the risk of fall. For instance, functional capacity, fall risk awareness, and physical activity may produce an accurate result when being used to predict the fall risk ${ }^{[16]}$.

We assumed that other single gait assessment may be effective in the predication of the risk of fall. Therefore, this study was to assess the prediction of falls in the elderly by using Functional Gait Assessment (FGA).

\section{SUBJECTS AND METHODS}

This study was a cross sectional study and used an analytical method to as- sess and describe aspects of the problems being studied. The study samples were 43 elderly who lived in the Panti Werdha Wana Seraya nursing home who met the inclusion criteria.

The variables of the study comprised the number of falls as dependent variable and score of FGA as independent variable. These variables were analyzed to predict fall in the elderly studied. FGA contains rating scales designed to examine the features of gait in the elderly as the effects of running, changing the speed of walking, walking while looking to the left and to the right, walking to look up and down, running by $180^{\circ}$ rotation, walking with step over shoe boxes, walking around shoe boxes, and going up and down stairs. The data of questioning and testing by FGA were collected by the researchers and analyzed descriptively as well as statistically.

\section{RESULTS}

Table 1 shows the characteristics of the elderly studied. Forty-three elderly living in Panti Werdha Wana Seraya (aged 60 -103 years, with a mean of $77.48 \pm 1.61$ years) were included in the study. There were 10 male subjects $(23.3 \%)$ and 33 female subjects $(76.7 \%)$ involved in the study. Table 2 shows the results of examinations by using FGA.

Table 1. Characteristics of study subjects

\begin{tabular}{ll}
\hline Characteristics & Value \\
\hline Aged (years) (Mean \pm SD) & $77.48 \pm 1.61$ \\
Male/ Female (person/percent) & $10(23.3 \%) / 33(76.7 \%)$ \\
Length of stay (years) $($ Mean \pm SD) & $10.3 \pm 1.33$ \\
\hline
\end{tabular}

Based on the history of falls in the last 3 months, it was found that 26 of 43 subjects $(60.4 \%)$ had 2 times falls. Regarding walking speed, 39 of 43 or $90 \%$ of the subjects had a walking speed of $<1 \mathrm{~m} / \mathrm{sec}-$ ond, which is within normal walking speed. Distribution of subjects based on walking ability showed 16 of $43(37 \%)$ 
subjects had decreased walking ability. Based on the ability to change the speed, most $(16 / 43$ or $37 \%)$ subjects had decreased walking ability. Nineteen of 43 subjects (44\%) had decreased ability to walk by looking to the right and to the left. Sixteen subjects $(37 \%)$ had decreased ability to walk by looking up and down. Based on the ability of the elderly to run by $180^{\circ}$ rotation and stop at the center, most (16/43 or $37 \%)$ had decreased ability. Based on the ability to walk with stepping a shoe box, most sub- jects $(25 / 43$ or $58 \%)$ had decreased ability. Based on the ability to walk around a shoe box it was found that most subjects $(16 / 43$ or $37 \%$ ) had decreased ability. Based on the ability to go up and down the stairs, most subjects (29/43 or $67.4 \%)$ had decreased ability. Result of bivariate analysis using Spearman rank correlation test showed that the coefficient correlation of the categorized scores of Functional Gait Assessment (FGA) and the number of falls was 0.36 with $p$-value of 0.009 .

Table 2. FGA results of the study subjects $(n=43)$

\begin{tabular}{ll}
\hline FGA examination & result \\
\hline Time for walking 6 meters (second) (Mean \pm SD) & $8.91 \pm 0.36$ \\
History of falls in the last 3 months (person/percent) & $26(60.4 \%)$ \\
Walking speed $<1 \mathrm{~m} / \mathrm{sec}$ (person/percent) & $39(90 \%)$ \\
Decreased walking ability (person/percent) & $16(37 \%)$ \\
Decreased ability to change the speed (person/percent) & $16(37 \%)$ \\
Decreased ability to walk by looking to the right and to the left (person/percent) & $19(44 \%)$ \\
Decreased ability to walk by looking up and down (person/percent) & $16(37 \%)$ \\
Decreased ability to run by $180^{\circ}$ rotation and stop at the center (person/percent) & $16(37 \%)$ \\
Decreased ability to walk with stepping a shoe box (person/percent) & $25(58 \%)$ \\
Decreased ability to walk around a shoe box (person/percent) & $16(37 \%)$ \\
Decreased ability to go up and down the stairs (person/percent) & $29(67.4 \%)$ \\
\hline
\end{tabular}

\section{DISCUSSION}

Frequency of falls in the elderly should ideally be only 1-2 times in one year ${ }^{[4]}$. The occurrence of falling more than 1 time in the last one year can likely increase the risk of occurrence of falls in the future ${ }^{[5]}$. The incidence of falls experienced by the majority of subjects in the survey conducted in the last 3 months was not the first occurrence of falls but it had happened at an earlier time. The high frequency of falls experienced by the elderly is influenced by various factors, both internal and external. Internal factors can affect them psychologically and activity. As for the external factors, one of them is gait. Internal factors that have high enough percentage to influence the occurrence of falls is a psychological condition and activity ${ }^{[6,7,8]}$. The psychic condition is strongly influenced by the psy- chological trauma of the fall ${ }^{[2,4,7]}$.

Elderly who have experienced previous falls can be more worried about their future, in particular about the ability to remain independent, because of loss of functional ability. The elderly may experience low self-esteem or fear of falling again, fear of not being able to do activities in daily life (ADL), or of social rejection, which in turn can lead to depression and withdrawal. The result is a decrease in activity, a further decline in the quality of life. Elderly who have fallen several times in the last 1 year should undergo evaluation of the falls associated with being dropped, and medical personnel may consider prescribing physical activity and exercising programs balanced by focusing on activities that can help reduce the risk of falling ${ }^{[7]}$.

Elderly who have lived long in the nurs- 
ing home and have long adapted to home conditions tend to experience less fall. It can be seen from 8 elderly subjects who had lived in the nursing home for between 2030 years who had never fallen in the last 3 months. Environmental factors are one of the external factors influencing the incidence of falls in the elderly. The incidence of falls will tend to decrease in an environment that is already known. Environmental conditions such as the position of the closet, the bathroom, the bed position that is too low and less lighting, may give risk of falling ${ }^{[8]}$.

Elderly who never experienced fall until there had severe injury are more likely choose not to do activity, as seen when they were asked to step over the shoe box they refused because they felt they were going to fall as well when asked to climb down the ladder they tended to hold and shake their body as they felt like falling, so while climbing the stairs they would prefer to take hold. The emergence of feeling to fall could be due to the trauma experienced before. Anxiety and depression will produce a feeling of falling. The elderly are particularly vulnerable to this problem. Environmental modifications can be done to reduce the appearance of feeling of fall often experienced by the elderly ${ }^{[8]}$.

Most of the study subjects were active elderly. Based on the study results, it was known that $41 \%$ of the elderly worked before living in Elderly Nursing home. Eighteen elderly before entering the nursing home had worked. The level of activity constitutes one of the causes of falls in the elderly, so the active elderly will have a greater risk of falling. Elderly with a background of having jobs that have a high frequency of activity will tend to choose to do a lot of activities after staying at the nursing home, to facilitate the daily manager of the elderly nursing homes to provide routine activities such as lectures, sufism, and gymnastics.

Based on the study results we know that elderly who had a work before do not necessarily have a greater risk of falling compared with the elderly who had not worked. The existence of these conditions may be due to the existence of other things that affect the risk of falls in the elderly in the home outside the factor of activity, which could be due to environmental factors such as less lighting and too low position of the bed and likely sight problems experienced by the elderly. The existence of an active condition in the elderly based on the theory of action is a success criterion of the aging process, but it should be kept in mind that too much activity will increase the risk of falling.

Most of the elderly in the elderly nursing home were aged between 74-84 years. The incidence of falls are intimately associated with the aging process in which the fall incident occurred in around $25 \%$ of elderly aged 65 years and increased to $35 \%$ in elderly aged 75 years and over ${ }^{[3]}$. As indicated in the findings, increase of age would also increase the risk of falling. It can be seen from the study results that four of the elderly aged more than 90 years had experienced more than 3 times falls in the last 3 months, and from 14 elderly aged between 65-74 years only 5 of them had never fallen in the last 3 months. Elderly have decreased function of the musculoskeletal system. One is a decrease in muscle strength. Strength or the amount of power generated by a muscle decreases with age. The decline in the elderly musculoskeletal system has a very big role in the occurrence of falls in the elderly, or it can be said that the decrease the musculoskeletal system purely belongs to the elderly which has an influence on postural balance. Muscle atrophy that occurs in the elderly causes a decrease in muscle strength, especially of the muscles of the lower extremities. Weakness of the lower extremity muscles can cause postural imbalance. This can lead to inactive moving, short steps, decreased cadence; feet cannot tread strong and tend to look shaky, difficult or too late to anticipate any interference like slipping and tripping. Some of these indicators can increase the risk of falls in the elderly. What should need to be considered is optimal monitoring and maintenance for the elderly who natu- 
rally have declining musculoskeletal system [9].

Results of the examination of the walking speed showed most of the elderly in this study had decreased ability, i.e. walking speed $<1 \mathrm{~m} / \mathrm{sec}$. The average speed of healthy women aged 75 years old is $1 \mathrm{~m} / \mathrm{sec}^{[10]}$. Collagen serves as the main supporter of the protein in the skin, tendons, bone, cartilage and connective tissue. Due to aging, collagen is changed into an irregular stretch and causes a decrease in a linear pull relationship. This decrease causes the tensile strength of collagen to start to decrease. Changes in collagen can lead to a decrease in muscle strength, while the muscle itself has decreased in the number and size of muscle fibers, which further causes a decrease in muscle strength. In action muscle fibers fast reaction (type II) is common in the elderly resulting in slow motion ${ }^{[1,10]}$.

Walking speed in elderly declines with age along with the change in the composition of the muscle and blood flow to the muscle reduced in line with the aging process. The decline in walking speed of elderly in this study may be due to psychological trauma caused by earlier incident of falls, in which the majority of the elderly never experienced more than 3 times - falls in the last 3 months. Elderly tend to be more careful and vigilant when walking so -by lowering their speed they feel more secure. A factor to consider is the level of activity that must be maintained in the elderly regarding the fact that reduced activity will also affect the muscle strength. The results of assessment during the study on the ability of the elderly in step run showed that most of the elderly in the home had shorter stride lengths as obtained by Elble et al., on testing 19 elderly of the average age of 76 years ie $0,25 \mathrm{~m} / \mathrm{step}$. Step length is reduced in the elderly may be due to reduced calf muscle strength so they cannot produce optimal plantar flexion, as well as possibly caused by the reduction in the balance and body control on the single stance phase ${ }^{[3]}$. Shortening step may be an appropriate response to a reduction in the balance, or perhaps especially because of the missing/ reduced muscle strength in the elderly. It could also be related to the sense of security - obtained when walking with short steps.

Results of this study on the two components of the examination with FGA have shown that the abilities of the elderly studied to walk and to change their walking speed were moderately decreased. It could be concluded that the incidence of falls in elderly was related to their postural instability. Muscle strength needs to maintain their postural equilibrium ${ }^{[10]}$. Muscle strength in elderly can be seen from their ability when given an instruction to walk for 20 seconds.

Balance is the process of maintaining the center of gravity projection, which falls on the runway cantilever- where the results of the entire workforce become zero; it is a complex process involving the arrest and coordination of sensory intake, motion planning- and the appearance of movements ${ }^{11}$. Elderly have decreased proprioception. This decline may increase the excitatory threshold muscle spindle, so as to break the afferent feedback and in sequence can alter the state of awareness of body position so to cause postural balance disorders. Central Nervous System (CNS) plays a role in maintaining the postural response. Central Nervous System via the pathways receives sensory information from the peripheral visual system, vestibular, and proprioceptive in the post-central gyrus' contralateral parietal lobe. Furthermore, this information is processed and integrated at all levels of the nervous system. Finally, latency within $\pm 150 \mathrm{~m} / \mathrm{sec}$ to form correct postural responses automatically and will be expressed in the effector mechanically through a series of specific movement patterns ${ }^{[11]}$.

Basic motion of a normal gait is the same for everyone. However, there is little difference in every movement made by each person as a typical gait pattern in each individual. An advocate of anti-gravity is needed to control the balance and movement forward. Mechanical stability is maintained along a path that passes through the gravity base buffer between the two legs. Elderly who were not able to perform according to instruction to change the speed 
of walking and run normally showed that the elderly impaired postural balance would affect the incidence of falls in the elderly. To improve walking ability in the elderly, we can do the balance exercise, namely physical activity undertaken to improve the stability of the body by improving lower extremity muscle strength ${ }^{[6,11]}$.

Results of this study on two components of the examination with FGA revealed that abilities of the elderly to walk with a look to the left and to the right and the ability to run by looking up and down were moderately decreased, respectively. Postural balance mechanism requires the cooperation and interaction of sensory systems, the central nervous system (CNS), and effector systems. The main sensory systems associated with postural balance system include visual, vestibular and proprioceptive. These visual receptors provide information about the orientation and position of the eyes, -the body or head to the surrounding environmental conditions. Vestibular organs provide information to the CNS about the position and movement of the head and eyesight through macular receptors and crest ampullaris located in the inner ear. CNS is needed in maintaining the postural response. Elderly who are not able to perform the instructions above normally indicate that the elderly have impaired postural balance. Postural balance- disorders can be caused by changes in the biomechanical components including myoelectric latency, time to react, proprioception; the range of motion and muscle strength. Old age is associated with reduced input proprioception, degenerative processes in the vestibular system, reflex slowing and weakening the position of muscle strength which are very important in maintaining posture. All these changes may contribute to the occurrence of falls, especially related to the level of - ability to prevent slipping or falling when facing situations that endanger the environment $\left.{ }^{[6,9}, 10\right]$.

Results of this study on four components of the examination are the ability of the elderly of running by $180^{\circ}$ rotation and then stop, walking around shoe box placed on the floor, passing the shoe box, and going up and down the stairs showed that they were moderately decreased. A group of movements of joints and muscles from both sides of the body, then the normal effector component must exist in order to perform normal movement of postural balance. Effector component required is the range of motion (ROM), strength and endurance of some muscle groups in legs, ankles, knees, hips, back, neck, and eyes. Disorders of the effector component will affect the ability to control posture that will make postural imbalance disorders. Walk with -toes in the direction of the lateral deviation of about $5 \%$ is an adaptation of the body to balance the lateral or suspected pelvic muscle weakness in charge of internal rotation. Joint movement may change with age. Decreased body rotation occurs due to secondary effects of joint stiffness ${ }^{[11]}$.

Fall occurs when the body's postural control system fails to detect a shift and reposition the center of gravity of the foundation supporting the right time to avoid loss of balance. This failure is partly due to the shift of the center of gravity of the body which is related to large, rapid and sudden environmental disturbances, as well as to intrinsic factors such as loss or reduction in sensory systems that are essential to the body's center of gravity motion detection, disorders of the central nervous system to organize and deliver postural response ineffective due to the disruption of the neuromuscular system, abnormal gait, postural reflexes are inadequate, joint instability, and muscle weakness. Gait assessment by examination with FGA, which consists of 8 items to assess capabilities of elderly of gait that can be seen and measured as mentioned above can be used as initial screening in the prevention of falls in the elderly so that complications caused by falls can be prevented, thus improving the quality of life of the elderly ${ }^{[8,9]}$.

There was a significant correlation between the score of functional gait assessment and the number of falls $(\mathrm{r}=0.36$, $\mathrm{p}<0.01)$. This result showed that most elderly in Elderly Nursing Panti Werdha 
Wana Seraya - had a high risk of falling and that score of FGA can predict the risk of fall in elderly. Gait is the one form of functional application gestures beside balance, strength, and flexibility- needed to maintain good posture. Good postures make ones can maintain their body to prevent fall ${ }^{[2]}$.

Gait disturbance experienced by the majority of the elderly indicates a problem with the dynamic postural balance, the presence of these problems will increase the risk of falls due to a disturbance in the process of the movement of the body. Influence of muscle strength on gait will cause a change in the strength of footing, walking speed, and stride length. Most of the elderly who have low muscle strength had a slow gait, with short steps, the foot could not tread strong and tended to look shaky. This condition can be improved through physical exercise. Physical exercise is expected to reduce the risk of falls by improving the strength of the legs and hands, balance, coordination, and reaction to environmental hazards. Physical exercise can also reduce the need for sedatives. Physical exercise is recommended in form of limb strength training, which should not to be too heavy, one of them is on the feet.

\section{CONCLUSIONS AND RECOMMEN- DATIONS}

\section{Conclusion}

Results of this study showed a correlation between score of FGA and the number of falls. According to the results, it can be concluded that FGA can be used to predict the risk of falls in elderly.

\section{Recommendations}

The examination on the prediction of fall should be included as one of the series of routine examinations performed every 3 months. Health care workers should perform balance exercises dynamic postural gymnastics alternately for the elderly as a modified form of activities and as one means of fall prevention in the elderly.

\section{REFERENCES}

1. King BM. Falls. In: Hazzard WR, Blass JP, Halter JB, Ouslander JG, Tinetti M, editors. Principles of geriatric medicine $\&$ gerontology $5^{\text {th }}$ ed. New York: McGraw-Hill; 2004. p. 1517-29.

2. Stocklager J, Schaeffer L. Pocketbook of elderly care in gerontologic. $2^{\text {nd }} \mathrm{Ed}$. New York: McGraw-Hill; 2008.

3. Darmojo B. Buku ajar geriatri (Ilmu Kesehatan Lanjut Usia). edisi ke-4. Jakarta: penerbit FKUI; 2009.

4. Susan LW, Gregory FM, Annika S, Diane M. The Sensitivity and Specificity of the Timed "Up \& Go" and the Dynamic Gait Index for Self-reported Falls in Persons with Vestibular Disorders. Journal of Vestibular research 2014; 14:397-409.

5. Barr R. Screening Elderly Women for Risk of Future Fracture - Participation Rate and Impact on Incidence of Falls and Fractures. Jurnal Calcified Tissue International 2015; 76:243-48.

6. Nugroho D. Panduan gerontologi tinjauan dari berbagai aspek. Jakarta: PT Gramedia Pustaka Utama; 2008.

7. Hile E, Studenski S. Instability and falls. In: Duthie EH, Katz PR, Malone ML, editors. Practice of geriatrics. $4^{\text {th }}$ ed. USA: Elsevier; 2007. p. 195-218.

8. Carpino C. New ideas in Balance and Falls Prevention, $3^{\text {rd }}$ Ed., St.Louis: Elsevier Saunders; 2007.

9. Alonso G, Elizabeth T, Hsiao W, Kunal K, Jennifer M, Wen L, Lewis F. Physical rehabilitation outcome measures. $4^{\text {th }}$ ed. Hamilton, Ontario, Canada: Lippincott Williams \& Wilkins; 2011.

10. Leiper W. Balance decrements in older persons: Effects of age and disease. In: Masdeu JC, Sudarsky L, Leiper W, editors. Philadelphia: Lippincott-Raven; 2011. p. 79-89.

11. Wolsfon T. Reliability of the Dynamic Gait Index in People with Vestibular Dis- 
orders. Arch Phys Med Rehabil 2012; 84:1528-33.

12. Y. El Miedany, M. El Gaafary, M. Toth, D. Palmer, and I. Ahmed, "Falls risk assessment score (FRAS): Time to rethink," J. Clin. Gerontol. Geriatr., vol. 2, no. 1, pp. 21-26, 2011.

13. M. R. Hassan, S. M. Arafat, and R. K. Begg, "Fuzzy-Genetic Model for the Identification of Falls Risk Gait," Procedia Comput. Sci., vol. 82, no. March, pp. 4-11, 2016.

14. E. Beghi et al., "Prediction of Falls in Subjects Suffering From Parkinson Disease, Multiple Sclerosis, and Stroke,"
Arch. Phys. Med. Rehabil., vol. 99, no. 4, pp. 641-651, 2018.

15. G. Allali, E. I. Ayers, and J. Verghese, "Multiple modes of assessment of gait are better than one to predict incident falls," Arch. Gerontol. Geriatr., vol. 60, no. 3, pp. 389-393, 2015.

16. N. B. Moreira, A. L. F. Rodacki, G. Pereira, and P. C. B. Bento, "Does functional capacity, fall risk awareness and physical activity level predict falls in older adults in different age groups?," Arch. Gerontol. Geriatr., vol. 77, no. April, pp. 57-63, 2018. 